Widdybank Fell and one or two other spots, shows us what late glacial Britain must have looked like, for its typical flora is still there in the shape of the Teesdale violet, the Teesdale sandwort and the other rarities of the region. The link between the two books is that it was Godwin, drawing on his vast experience of post-glacial British flora, who put forward this thesis, now amply proven by the extensive research reported in Roy Clapham's book. We might never have had this book at all, and botanists might have been happy to go on theorising about the origin of the Teesdale flora forever, but for the catalytic (perhaps cathartic would be a better word) effect of Cow Green Reservoir. The strenuous efforts by botanists to prevent the submergence of part of the lower slopes of the historic Widdybank Fell site failed, but did lead to the offer by ICI of $£, 100,000$ to promote research into the area they were about partly to destroy. Hence the Teesdale Trust, and hence this excellent survey, which is now pretty comprehensive for the flowering plants of the area, though much less so for the lower plants and the admittedly somewhat less interesting invertebrates.

Both books are musts for anybody who wishes to understand how our countryside came to assume its present appearance and how it came to be occupied by the various kinds of wildlife.

RICHARD FITTER

\title{
The Last Great Wild Beast Show, by Bill Jordan and Stefan Ormerod. Constable, $£ 6.50$.
}

This is largely an anthology of horror stories about British animal collections, with a digression on the abominations of wildlife traffic and a passing rebuke for the far greater ravages of the pet, fur and skin trades. Such exposure is salutary and the authors' zeal for animal welfare is patent, but their tone seems calculated to put all heaven in a rage rather than to promote practical improvements. They denounce not only the commercial zoos, with their fun-fairs and gift shops, and the safari parks, which have 'spread like an insidious cancer that is antagonistic to the whole principle of wildlife preservation', but also the non-profit-making 'mainstream' zoos which, in trying to be comprehensive, have become 'cumbersome dinosaurs'. They are aware of degrees of culpability but their loosely constructed book is in danger of muddling together in a general condemnation both the zoos that are indefensibly bad and the respectable ones that merely fail to conform with the authors' exacting and puritanical philosophy. $\mathrm{Mr}$ Jordan and Mr Ormerod want to abolish all these and allow only specialist collections, serviced by highly trained and well paid staffs, dedicated to research, education and conservation on the lines pioneered by 'men like Peter Scott, Philip Wayre and Gerald Durrell' - although, regrettably, even these 'are obliged to provide facilities for the paying visitor'.

They have a case eminently worth arguing but, even if it should be accepted (and the finance made available) in some distant future, the zoos and parks will be with us for many years to come, while their recent proliferation makes it all the more necessary to check the present cruel and wasteful exploitation of wildlife. This implies education of public opinion, persuasion of zoo-men and, finally, legislation. The book may make readers angry but contributes little to any of these approaches. True, at one point the authors confide that 'the solution rests in a change of public attitudes' yet on another page they contradict themselves (or one another?) by contemptuously dismissing 'the ill-advised policy of giving the public what it wants'. Their sweeping accusations of 'ignorance, stupidity and neglect' are unlikely to persuade zoo people to mend their ways, nor is their approving quotation of 'the law is a ass-a idiot' likely to further desirable legislation. Perhaps it would be more constructive if, for instance, the authors used their expert knowledge to fight ignorance in the worst type of zoo by compiling an elementary handbook on animal care-written with the same sympathetic understanding for zoo-men that they show for other primates. Their admirable organisations might well finance this and also a less confusing summary of our present legislation and its inadequacies both in scope and enforcement but without insistence on the 'farcical' nature of Parliament's previous efforts. Indignation is not enough. 